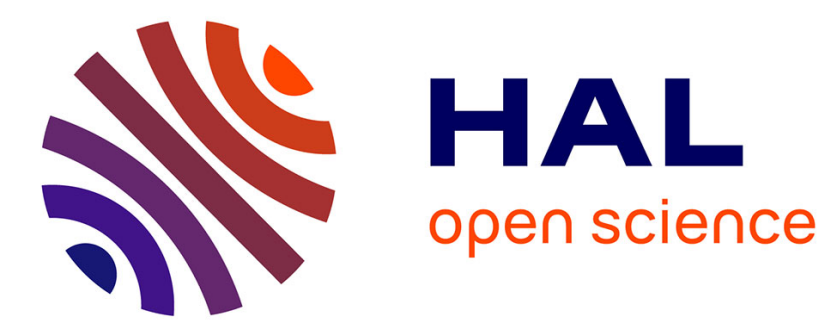

\title{
A tribute to Professor Juan Faus Payá
}

Miguel Julve, Francesc Lloret, Michel Verdaguer

\section{To cite this version:}

Miguel Julve, Francesc Lloret, Michel Verdaguer. A tribute to Professor Juan Faus Payá. Journal of Coordination Chemistry, 2018, 71 (5), pp.585-589. 10.1080/00958972.2018.1443217 . hal-01755342

\section{HAL Id: hal-01755342 https://hal.sorbonne-universite.fr/hal-01755342}

Submitted on 30 Mar 2018

HAL is a multi-disciplinary open access archive for the deposit and dissemination of scientific research documents, whether they are published or not. The documents may come from teaching and research institutions in France or abroad, or from public or private research centers.
L'archive ouverte pluridisciplinaire HAL, est destinée au dépôt et à la diffusion de documents scientifiques de niveau recherche, publiés ou non, émanant des établissements d'enseignement et de recherche français ou étrangers, des laboratoires publics ou privés. 
A tribute to Professor Juan Faus Payá

Journal of Coordination Chemistry, March 2018

Doi : 10.1080/00958972.2018.1443217

\author{
Julve Miguel ${ }^{\mathrm{a} *}$ \\ Lloret Francesc ${ }^{\text {a }}$ \\ Verdaguer Michel ${ }^{\mathrm{b}}$ \\ ${ }^{a}$ Quimica Inorganica/ICMol, Universitat de Valencia, Valencia, Spain \\ Université, Paris, France \\ * Corresponding author. Email: miguel.julve@uv.es \\ (C) 2018 Informa UK Limited, trading as Taylor \& Francis Group
}

${ }^{\mathrm{b}}$ Institut Parisien de Chimie Moléculaire, UMR CNRS 8232, Université Pierre et Marie Curie, Sorbonne

It is for us a pleasure, an honor, and a privilege to pay tribute to Professor Juan Faus in this special Issue of the Journal of Coordination Chemistry celebrating his retirement from the University of Valencia.

The three authors have very close and friendly long-lasting relations with Professor Faus even in different contexts. Two of us (FL, MJ) received their chemical education from him and became his close co-workers, whereas the third one (MV) developed a tight Spanish-French collaboration between the team of Professor Faus in Valencia and the laboratory of Olivier Kahn at Orsay in the 1980s and then with his group in Paris in the 1990s.

Professor Faus is a scholar with a wide and deep culture. Even if his well-known modesty suffers, we would like to underline some of his achievements in teaching and research activities (Figure 1).

\title{
The teacher
}

Professor Faus was appointed as an Assistant Professor in 1968 at the Department of Inorganic Chemistry of the University of Valencia. He became Full Professor at the same Institution in 1980. He held this position until his retirement in 2017, after almost 50 years of continuous dedication to the University. Amazingly, he decided to continue to work in the old Inorganic Chemistry building of the university, even when the new and more functional buildings of the Institute of Molecular Chemistry (ICMol) became available. His passion for teaching induced him to stay closer to the students by remaining in the old building.

Professor Faus was, and remains, a great teacher. He taught many generations of students. His lectures, perfectly clear, organized and documented, the care brought to help the students are unanimously appreciated and recognized by his students and colleagues. In this respect, M. Julve, one of his former students, can testify that the students were so delighted with Professor Faus's classes that they asked him to extend them after the end of the academic year, which he did with pleasure.

He was accustomed to receive the students between his classes to answer kindly their questions. He had a special ability to listen, to instil confidence, to push everyone to reach her/his full potential, and to recognize in each her/his individual skills. His present co-workers are indebted to him for such confidence and permanent support.

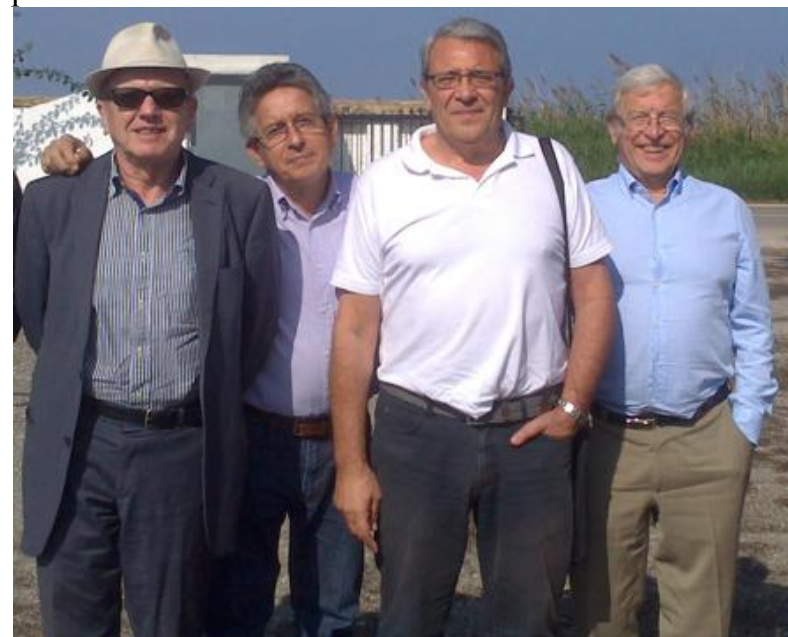

Figure 1. Juan Faus, going for a lunch at the Albufera, after a working session in the university. From left to right: J. Faus, M. Julve, F. Lloret, and M. Verdaguer. 


\section{The researcher and group leader}

Prof. Faus and his former PhD, Prof. José María Moratal, created the research group of Coordination Chemistry at the Department of Inorganic Chemistry of the University of Valencia in 1976. Before this date, his first publication appeared in "Quimica Analitica". It concerned analytical chemistry, the identification of alkaline cations by paper chromatography using the reaction of dihydrogen sulfide with alkali metal violurates. It is cosigned by the Head of Inorganic Chemistry in Valencia at that time. In the mid-1970s, Spain knew a sudden burst of changes and hopes in many aspects of the social life. It is significant that the new group was born at this time. Juan Faus and his first students (Moratal, Lloret, Julve, and Garcia-España) first focused on the determination of stability constants of metal complexes in solution with violurate (a very strong field ligand), catechol, porphyrins, and Schiff base ligands. The techniques used were potentiometry and spectrophotometry. A few years later, a Spanish governmental program allowed talented young Spanish scientists to visit abroad as postdoctoral fellows. With the support of Professor Faus, Miguel Julve was the first to seize this opportunity and he spent two years in France in the laboratory of Prof. Oliver Kahn at Orsay where he worked closely with M. Verdaguer. Others (Moratal, Garcia-España) visited the groups of Bertini and Paoletti in Florence (toward bioinorganic chemistry and supramolecular chemistry) and found their own way. This national and European opening-up transformed deeply Faus's group and beyond, the Inorganic Chemistry Department. It brought new blood, modernized and diversified the themes, and opened the way to publications in European and American journals. From then, the programmed postdoctoral stays of members of Faus's group in France (Orsay) (M. Julve then F. Lloret working with Y. Journaux and later, J. A. Real working with J. Zarembowitch on spin cross-over) and their reincorporation in the mother group in Valencia allowed achievement of a solid background in solidstate coordination chemistry, in structural studies and in magnetism. Furthermore, some of the systems investigated by Professor Faus underwent spin changes [complexes of $\mathrm{Co}(\mathrm{II})$ and $\mathrm{Fe}(\mathrm{II})$ with violurate and its alkyl derivatives] and led him to be interested in Molecular Magnetism. New equipment, a variable-temperature Faraday balance permitted to carry out this new research avenue at home, always keeping and reinforcing the collaboration with foreign teams. Along the years, the scientific partnership transformed into reciprocal esteem and friendship.

The group is located nowadays in the premises of the Institute of Molecular Science of Valencia and is constituted by two Full Professors (Miguel Julve and Francesc Lloret), one Assistant Professor (Isabel Castro), a lecturer (Salah Eddine-Stiriba), two permanent researchers (Joan Cano and Rafael Ruiz), four hired researchers [Emilio Pardo and F. José Martínez (Ramón and Cajal positions), Marta Viciano (Juan de la Cierva position), and Luminita Toma (Marie Skłodowska-Curie, H2020, position] and one technician (F. Nicolás Moliner).

Professor Faus supervised a good number of Ph.D. Theses. Most of his doctoral students occupy permanent positions in public institutions, beyond the coordination chemistry group itself: Enrique García-España and Miguel Mollar are Full Professors at the University of Valencia and Universidad Politécnica de Valencia, respectively; Hermás Jiménez is an Assistant Professor at the University of Valencia; Maria Luisa Calatayud is Full Professor in a secondary public school; abroad, Raúl Chiozzone, Ricardo González, and Alicia Cuevas are Assistant Professors at the Universidad de la República, Montevideo, Uruguay.

Professor Faus promoted international collaborations of his team with national and foreign Institutions. The international exchange was especially strong and fruitful in the framework of the European Union where the Coordination Chemistry group was involved as a partner in several bilateral Spanish-French "Picasso" integrated actions $(1990,1991,1993)$ with teams in France (Paris and Orsay) and in Spain (Valencia and Barcelona) and then in European networks. This collaboration, led at the beginning by Professors Faus and M. Verdaguer and then by their co-workers, followed the initial interest of Professor Faus for combined solution and solid-state studies and was dedicated to metal complexes with oxalate, oximes, functionalized oxamate/oxamidate derivatives, $2,2^{\prime}$-bipyrimidine, squarate, and croconate as ligands. The choice of these ligands was mainly based on both their great versatility as bridges between transition metals and their potential ability to mediate exchange interactions between the bridged paramagnetic centers.

This management and scientific strategy had many positive consequences: (i) beautiful scientific results (about 150 articles) on original chemical systems published in prestigious journals (J. Am. Chem. Soc., Angewandte Chemie, Inorg. Chem., Dalton Transactions, etc.); (ii) a long-term exchange program for training of doctoral and postdoctoral fellows in the 1990s and later (I. Castro is now Assistant Professor in Valencia and R. Lescouëzec is Full Professor in Paris); (iii) close association of the Coordination Chemistry group in the European networks launched in the frame of 4th-6th PCRD.

Other very fruitful international collaborations were established later (from 1999), on another Professor Faus's favorite topic, the chemistry and the magnetic properties of rhenium(IV), a paramagnetic and highly anisotropic metal ion. The collaboration involved Prof. Carlos Kremer and his co-workers from the Universidad de la República (Uruguay) and also the Italian group of Professors G. De Munno and D. Armentano.

One can state that Professor Faus, after the studies first published by the Polish and Russian schools on halogenorhenates(IV), established in a very creative way a new coordination chemistry of Re(IV) to exploit the 
remarkable magnetic anisotropy of this ion. Three $\mathrm{PhD}$ co-shared theses issued from the Uruguayan collaboration on $\operatorname{Re}(\mathrm{IV})$ together with 37 published articles with Professor Faus as co-author. The intensity and the quality of this research, up to a recent Nature Communications paper, pushed the Valencia group to the first world rank for research on Re(IV) coordination chemistry. These achievements were summarized in a recent review.

Professor Faus was distinguished with the Gascó Oliag Medal on 14 November 2009 by the Colegio de Químicos de la Comunitat Valenciana for his brilliant teaching and high-level research as well as his continuous collaboration with the Colegio de Químicos.

\section{The man and the friend}

We would like to conclude this tribute to evoke more personal memories.

Juan Faus is a quiet, modest, and friendly man, always ready, after work, to enjoy life with friends (Figure 2).

We cannot remember him in the university dressed without his clean white over-garment and his friendly teasing smile. Juan Faus is a man who is always ready to face adversity and find the right solutions. He enjoys life, likes his town (Valencia), its paella, and quiet boat cruises on the Albufera. He liked to share his lunch in the university restaurant with colleagues and friends and, open-minded, he was not the last to participate in vivid discussions where the world is passionately rebuilt every day on firmer and more rational bases.

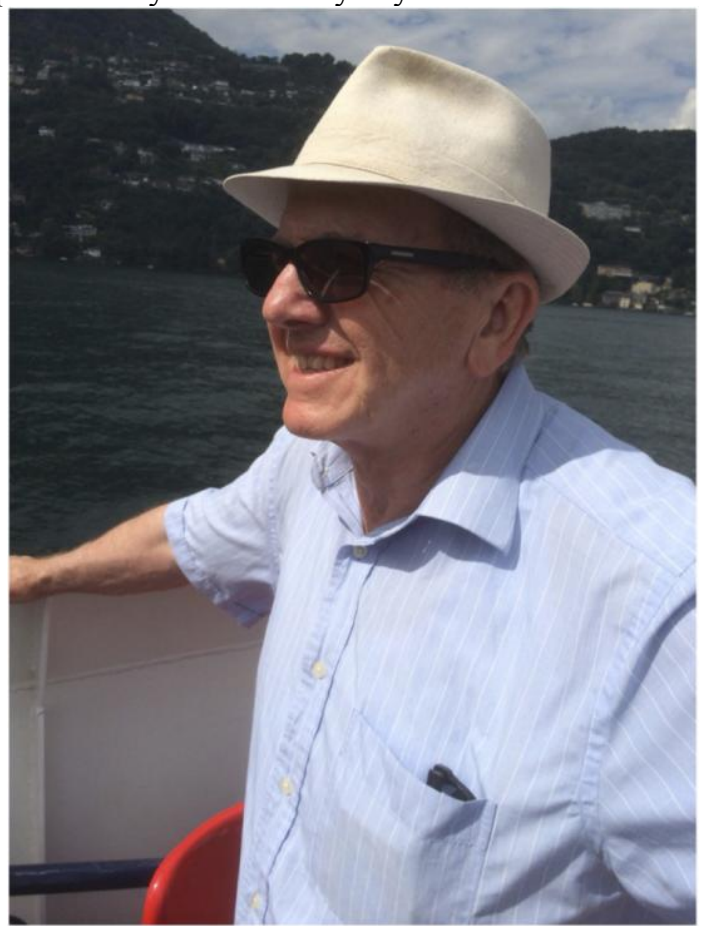

Figure 2. A recent portrait of Professor Faus enjoying boating under the sun.

We are sure that all his collaborators and colleagues join us in thanking Prof. Faus for his invaluable contributions to the development of Coordination Chemistry in Spain and worldwide. We wish him all the best for his retirement.

To conclude, we are convinced that this special issue will contribute to the recognition of his scientific legacy and his high-quality work which exerts a strong influence not only on the past generations of chemists, but also on the present and future ones. 